\title{
Penerapan Custom Core System Class pada Pengembangan Sistem Informasi Manajemen Donasi
}

The Implementation of Custom Core System Class in the Development of Donation Management Information System

\author{
Ahmad Farisi ${ }^{1}$, Kgs. Achmad Siddik ${ }^{2}$, Aini Algharizah ${ }^{3}$, Handri $^{4}$ \\ ${ }^{1,2,3}$ Program Studi Sistem Informasi, STMIK Global Informatika MDP \\ E-mail: ${ }^{1}$ ahmadfarisi@mdp.ac.id, ${ }^{2}$ siddiqachmad@mdp.ac.id, \\ ${ }^{3}$ handriberiman@mhs.mdp.ac.id, ${ }^{4}$ ainialgharizah@mhs.mdp.ac.id
}

\begin{abstract}
Abstrak
Pengembangan sistem informasi saat ini lebih banyak dilakukan pada platform web dibandingkan pada platform lainnya seperti mobile ataupun desktop. Dalam pengembangan sistem informasi berbasis web, banyak teknologi penunjang yang dapat digunakan seperti framework-framework yang diciptakan untuk meningkatkan kinerja dan keamanan aplikasi web. Framework-framework tersebut antara lain framework PHP, framework CSS, dan framework JS. Penelitian ini secara khusus membahas penggunaan core system class yang dibuat secara custom pada framework CodeIgniter yang merupakan salah satu dari beberapa framework PHP yang ada. Penelitian ini mengambil Yayasan XYZ, yang merupakan salah satu Yayasan Sosial yang berlokasi di Kota Palembang, sebagai studi kasus untuk mengembangkan sebuah sistem informasi manajemen donasi dengan menerapkan custom core system class dari framework CodeIgniter. Setelah diuji menggunakan webuse method, sistem informasi yang dikembangkan dengan menerapkan custom core system class ini menunjukkan nilai usability 0,875 yang berarti sangat baik. Hal ini menunjukkan bahwa dari sudut pandang usability aplikasi web, sistem informasi yang dikembangkan dengan menerapkan custom core system class ini memberikan hasil yang sangat baik.
\end{abstract}

Kata kunci: Sistem Informasi Manajemen Donasi, Custom Core System Class, CodeIgniter, Webuse Method

\begin{abstract}
The development of information systems today are mostly done on web platforms rather than other platforms such as mobile or desktop. On the development of web based information systems, many supporting technologies can be used to improve the performance and security of web applications such as frameworks. These frameworks include PHP framework, CSS framework, and JS framework. This research specifically discusses the use of custom-made core system classes in the Codeigniter framework which is one of several existing PHP frameworks. This research takes the XYZ Foundation as a case study to develop a donation management information system by implementing a custom core system class from the CodeIgniter framework. The XYZ Foundation is one of the Social Foundation located in Palembang. After being tested using the webuse method, the information system developed by implementing a custom core system class shows a usability value of 0.875 which means very good. From the perspective of web application usability, this usability result shows that the information system developed by implementing a custom core system class provides very good results.
\end{abstract}

Keywords: Donation Management Information System, Custom Core System Class, CodeIgniter, Webuse Method 


\section{PENDAHULUAN}

Penggunaan SaaS atau Cloudware pada perangkat lunak dan penggunaan aplikasi web saat ini menjadi semakin populer, khususnya untuk kebutuhan pengarsipan, kantor, manajemen, hingga sistem informasi [1]. Hal ini menunjukkan pengembangan sistem informasi saat ini lebih banyak dilakukan pada platform web dibandingkan pada platform lainnya seperti mobile ataupun desktop. Sistem informasi berbasis web atau yang disebut juga dengan WBISs (Web Based Information Systems) [2] adalah sistem informasi yang menggunakan teknologi web Internet untuk memberikan informasi dan layanan kepada pengguna. Teknologi ini adalah sistem perangkat lunak yang digunakan untuk mempublikasikan dan memelihara data dengan prinsip hypertext [3].

Dalam pengembangan sistem informasi berbasis web, banyak teknologi penunjang yang dapat digunakan untuk meningkatkan kinerja dan keamanan aplikasi web seperti teknologi framework pada PHP, CSS, dan JS yang bekerja pada client side dan server side. Pada sisi server side, framework PHP akan lebih banyak digunakan, khususnya pada sisi back end dari sistem. Sementara framework CSS dan JS akan lebih banyak digunakan pada sisi front end dari sistem. Salah satu framework PHP yang saat ini masih banyak digunakan adalah CodeIgniter. Data yang didapatkan dari similartech menunjukkan bahwa sampai saat ini CodeIgniter masih banyak digunakan.

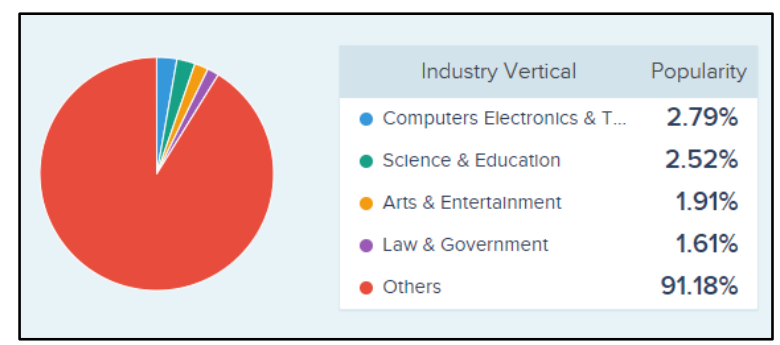

Gambar 1 Statistik Industri Pengguna Framework Codeigniter [4]

Beberapa penelitian sebelumnya yang juga menggunakan framework CodeIgniter untuk pengembangan sistem informasi berbasis web adalah penelitian [5] yang mengembangkan aplikasi ujian online pada Sekolah Menengah Kejuruan (SMK). Aplikasi tersebut kemudian diuji menggunakan User Acceptance Testing (UAT). Hasilnya menunjukkan bahwa aplikasi tersebut sangat cocok untuk diterapkan dan dapat digunakan dengan baik oleh siswa/i yang menggunakannya. Penelitian lainnya mengembangkan specific model pada proses CRUD yang dilakukan dengan menggunakan framework CodeIgniter [6]. Model yang dikembangkan melakukan pemetaan helper dan library yang ada pada CodeIgniter menjadi satu model custom untuk melakukan proses CRUD ke dalam basis data MySQL. Hasilnya menunjukkan model yang dikembangkan dapat melakukan proses CRUD dengan baik. Penelitian lainnya menerapkan model Kirkpatrick untuk mengembangkan sistem informasi berbasis web untuk mengevaluasi kegiatan mengajar guru, performa siswa/i di luar kelas, dan tren institusi pendidikan dari tahun ke tahun di SMK [7]. Adapun pengembangan sistem informasinya juga menggunakan framework CodeIgniter. Hasilnya menunjukkan sistem informasi yang dikembangkan dapat membantu pihak sekolah dalam melakukan evaluasi terhadap kegiatan mengajar guru, performa siswa/i di luar kelas, dan tren institusi pendidikan dari tahun ke tahun di SMK.

Seperti penelitian-penelitian sebelumnya, penelitian ini juga mengembangkan sistem informasi berbasis web menggunakan framework CodeIgniter. Namun penelitian ini menerapkan core system class yang dibuat secara custom untuk membantu sistem melakukan proses Create Retrieve Update Delete (CRUD) dari dan ke basis data MySQL. Penelitian ini mengambil studi kasus pada Yayasan XYZ yang merupakan salah satu Yayasan yang bergerak 
di bidang sosial di Kota Palembang. Berdasarkan hasil observasi penulis terhadap Yayasan $\mathrm{XYZ}$, diperlukan adanya sebuah sistem yang dapat membantu Yayasan dalam mengelola kegiatan donasi yang secara rutin diselenggarakan pihak Yayasan setiap bulan.

Berdasarkan studi terhadap beberapa penelitian sebelumnya dengan melihat permasalahan yang ada pada studi kasus, maka penelitian ini melakukan pengembangan sebuah sistem informasi manajemen berbasis web yang mengelola kegiatan donasi dari Yayasan XYZ dengan menerapkan core system class yang dibuat secara custom.

\section{METODOLOGI PENELITIAN}

Penelitian ini dilakukan dengan mengikuti langkah-langkah metodologi penelitian perumusan masalah, studi literatur, penyusunan instrumen penelitian, pengumpulan data, analisis data, pengembangan sistem informasi, dan penarikan kesimpulan.

\subsection{Perumusan Masalah}

Perumusan masalah dari penelitian ini adalah 1. Bagaimana mengembangkan sebuah sistem informasi manajemen donasi berbasis web yang dapat mengelola kegiatan donasi dari Yayasan XYZ, 2. Bagaimana menerapkan custom core system class pada sistem informasi yang dikembangkan, 3. Bagaimana hasil dari sistem informasi yang dikembangkan.

\subsection{Studi Literatur}

Penelitian ini merujuk kepada beberapa penelitian terdahulu yang juga menerapkan CodeIgniter sebagai framework pengembangan sistem informasi berbasis web. Beberapa penelitian tersebut dapat dilihat pada Tabel 1.

Tabel 1 Penelitian Terdahulu

\begin{tabular}{|c|c|c|c|}
\hline Penulis & Tahun & Judul & Uraian \\
\hline $\begin{array}{l}\text { Wibawa, S. C. } \\
\text { Wahyuningsih, Y. } \\
\text { Sulistyowati, R. } \\
\text { Abidin, R. } \\
\text { Lestari, Y. } \\
\text { Noviyanti } \\
\text { Maulana, D. A. }\end{array}$ & 2018 & $\begin{array}{c}\text { Online Test Application } \\
\text { Development Using } \\
\text { Framework Codeigniter }\end{array}$ & $\begin{array}{l}\text { Penelitian ini mengembangkan aplikasi ujian online pada } \\
\text { Sekolah Menengah Kejuruan (SMK) menggunakan } \\
\text { framework CodeIgniter. Aplikasi tersebut kemudian diuji } \\
\text { menggunakan User Acceptance Testing (UAT). Hasilnya } \\
\text { menunjukkan bahwa aplikasi tersebut sangat cocok untuk } \\
\text { diterapkan dan dapat digunakan dengan baik oleh siswa/i } \\
\text { yang menggunakannya. }\end{array}$ \\
\hline $\begin{array}{l}\text { Fadhilah, Muchammad } \\
\text { Kukuh } \\
\text { Surantha, Nico } \\
\text { Isa, Sani M }\end{array}$ & 2018 & $\begin{array}{c}\text { Web-Based Evaluation } \\
\text { System using Kirkpatrick } \\
\text { Model for High School } \\
\text { Education ( A Case } \\
\text { Study for Vocational } \\
\text { High School in Jakarta) }\end{array}$ & $\begin{array}{l}\text { Penelitian ini menerapkan model Kirkpatrick untuk } \\
\text { mengembangkan sistem informasi berbasis web untuk } \\
\text { mengevaluasi kegiatan mengajar guru, performa siswa/i di } \\
\text { luar kelas, dan tren institusi pendidikan dari tahun ke tahun } \\
\text { di SMK. Adapun pengembangan sistem informasinya juga } \\
\text { menggunakan framework CodeIgniter. Hasilnya } \\
\text { menunjukkan sistem informasi yang dikembangkan dapat } \\
\text { membantu pihak sekolah dalam melakukan evaluasi } \\
\text { terhadap kegiatan mengajar guru, performa siswa/i di luar } \\
\text { kelas, dan tren institusi pendidikan dari tahun ke tahun di } \\
\text { SMK. }\end{array}$ \\
\hline $\begin{array}{l}\text { Arrhioui, Karim } \\
\text { Mbarki, Samir } \\
\text { Betari, Oualid } \\
\text { Roubi, Sarra } \\
\text { Erramdani, Mohammed }\end{array}$ & 2017 & $\begin{array}{c}\text { A Model Driven } \\
\text { Approach for Modeling } \\
\text { and Generating PHP } \\
\text { CodeIgniter based } \\
\text { Applications }\end{array}$ & $\begin{array}{l}\text { Penelitian ini mengembangkan specific model pada proses } \\
\text { CRUD yang dilakukan dengan menggunakan framework } \\
\text { CodeIgniter. Model yang dikembangkan melakukan } \\
\text { pemetaan helper dan library yang ada pada CodeIgniter } \\
\text { menjadi satu model custom untuk melakukan proses CRUD } \\
\text { ke dalam basis data MySQL. Hasilnya menunjukkan model } \\
\text { yang dikembangkan dapat melakukan proses CRUD dengan } \\
\text { baik. }\end{array}$ \\
\hline
\end{tabular}




\begin{tabular}{|l|l|l|l|}
\hline $\begin{array}{l}\text { Das, Ripunjit } \\
\text { Saikia, Lakshmi Prasad }\end{array}$ & 2016 & $\begin{array}{c}\text { Comparison of } \\
\text { Procedural PHP with } \\
\text { Codeigniter and Laravel } \\
\text { Framework. }\end{array}$ & $\begin{array}{l}\text { Penelitian ini membandingkan kinerja dari plain PHP, } \\
\text { framework CodeIgniter, dan framework Laravel dalam } \\
\text { melakukan operasi CRUD ke dalam basis data MySQL. } \\
\text { Parameter pembandingnya adalah execution time dan } \\
\text { penggunaan memori. Hasilnya menunjukkan kinerja } \\
\text { execution time dari framework Laravel unggul dibandingkan } \\
\text { framework Codelgniter dan plain PHP. Sementara dari sisi } \\
\end{array}$ \\
& $\begin{array}{l}\text { pengunaan memori, plain PHP dan framework CodeIgniter } \\
\text { lebih unggul dibandingkan framework Laravel yang lebih } \\
\text { banyak mengkonsumsi memori. }\end{array}$ \\
\hline
\end{tabular}

\subsection{Penyusunan Instrumen Penelitian}

Instrumen penelitian yang digunakan dalam penelitian ini adalah kuesioner dan wawancara. Kuesioner digunakan dalam menguji usability dari sistem informasi yang dihasilkan, adapun kuesioner ini disusun berdasarkan webuse method [8]. Sementara wawancara yang dilakukan dalam penelitian ini digunakan untuk mengumpulkan data dari narasumber Yayasan XYZ.

\subsection{Pengumpulan Data}

Data-data yang dikumpulkan dalam penelitian ini berupa dokumen-dokumen dari Yayasan XYZ seperti laporan penerimaan dan penyaluran donasi, serta laporan data donatur dan mustahiq. Data-data ini kemudian dijadikan landasan dalam pengembangan sistem informasi manajemen donasi pada Yaysan XYZ. Selain itu, data-data lainnya didapatkan dengan melakukan wawancara kepada pengurus Yayasan XYZ pada 22 Agustus 2019 pukul 15.30 s.d. 16.30 WIB untuk menggali beberapa permasalahan yang terjadi di Yayasan XYZ yang dapat diselesaikan dengan bantuan teknologi informasi. Beberapa permasalahan tersebut adalah media transparansi keuangan Yayasan yang belum dipublikasi secara umum, notifikasi waktu donasi kepada para donatur yang dinilai belum optimal, pengarsipan bukti transaksi yang belum didukung teknologi informasi, dan pengarsipan laporan keuangan yang perlu dikembangkan ke media online yang dapat dipublikasi secara online dan transparan.

\subsection{Analisis Data}

Analisis yang dilakukan pada penelitian ini dibagi ke dalam 2 bagian. Pertama, analisis dilakukan terhadap data yang telah dikumpulkan. Data-data tersebut dianalisis untuk memetakan solusi teknologi informasi terhadap beberapa permasalahan yang terjadi pada Yayasan XYZ. Metode analisis data yang digunakan adalah PIECES [9] yang dapat menganalisis permasalahan dengan parameter pada Tabel 2 .

Tabel 2 Analisis Permasalahan

\begin{tabular}{|l|l|}
\hline \multicolumn{1}{|c|}{ PIECES } & \multicolumn{1}{c|}{ PERMASALAHAN } \\
\hline Performance & $\begin{array}{l}\text { Aktivitas Yayasan seperti pengumpulan hingga penyaluran donasi, publikasi donasi, dan pengarsipan bukti } \\
\text { transaksi membutuhkan alat bantu teknologi informasi yang dapat memperbaiki, merapikan, dan mempercepat } \\
\text { kinerja Yayasan. }\end{array}$ \\
\hline Information & $\begin{array}{l}\text { Dibutuhkan informasi pemasukan dan pengeluaran donasi secara transparan dari Yayasan kepada donatur secara } \\
\text { online dan up to date. }\end{array}$ \\
\hline Economic & $\begin{array}{l}\text { Beberapa aktivitas Yayasan dapat dikurangi dengan bantuan teknologi informasi, seperti notifikasi donasi } \\
\text { kepada donatur yang dilakukan setiap bulan saat ini dilakukan melalui telepon. }\end{array}$ \\
\hline Control & $\begin{array}{l}\text { Bukti-bukti transaksi dan pembelian sembako butuh diarsipkan juga secara digital untuk mempermudah } \\
\text { pencarian data tersebut apabila dibutuhkan. }\end{array}$ \\
\hline Efficiency & $\begin{array}{l}\text { Beberapa aktivitas Yayasan masih membutuhkan waktu yang cukup lama dalam pelaksanaannya, seperti } \\
\text { pencarian arsip bukti transaksi, dokumentasi laporan donasi, dan penyimpanan data-data donatur dan mustahiq. }\end{array}$ \\
\hline Service & $\begin{array}{l}\text { Dibutuhkan media yang dapat menjadi sarana bagi donatur, mustahiq, dan masyarakat dalam mengakses data- } \\
\text { data keuangan Yayasan. }\end{array}$ \\
\hline
\end{tabular}

Analisis kedua dilakukan terhadap core system class yang dikembangkan secara custom dalam penelitian ini. Beberapa hal yang dapat dilakukan untuk menciptakan custom core system class tersebut adalah 1. Membuat model yang dirancang secara khusus untuk melakukan operasi CRUD, 2. Membuat custom core system class dengan nama MY_Controller yang meng-extends class CI_Controller untuk kebutuhan paging, CRUD, dan upload file, dan 3. Menerapkan custom core system class di dalam Controller sesuai dengan kebutuhan. 


\subsection{Pengembangan Sistem Informasi}

Pengembangan sistem informasi manajemen donasi yang dilakukan dalam penelitian ini menggunakan model iterasi. Model ini dipilih berdasarkan kebutuhan pengembangan sistem dengan memperhatikan kriteria-kriteria kejelasan kebutuhan pengguna, penguasaan teknologi, tingkat kerumitan dan kehandalan sistem, waktu pelaksanaan, dan visibilitas jadwal pelaksanaan sebagaimana yang dijelaskan [10] dalam studinya tentang analisis pemilihan penerapan proyek metodologi pengembangan rekayasa perangkat lunak. Model iterasi merupakan metodologi yang mengandalkan pembangunan aplikasi perangkat lunak satu langkah pada satu waktu dalam bentuk memperluas model [11]. Model ini didasarkan pada spesifikasi awal dari sistem yang dibangun. Setelah diuji dan umpan balik diterima, maka selanjutnya disesuaikan dengan rencana pengembangan sistem sebelumnya. Proses ini diulang sampai menjadi sistem yang berfungsi penuh untuk memenuhi semua kebutuhan sistem.

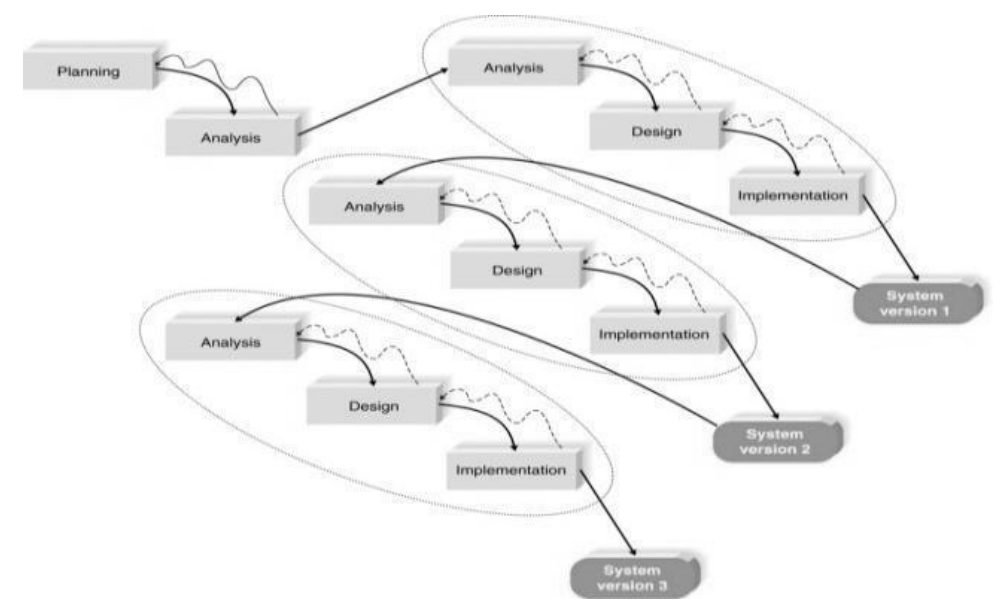

Gambar 2 Model Iterasi Dalam Pengembangan Perangkat Lunak [10]

\subsection{Penarikan Kesimpulan}

Kesimpulan dari penelitian ini dapat ditarik setelah melakukan pengembangan sistem informasi dan melakukan evaluasi terhadap usability sistem yang dihasilkan untuk menjawab perumusan masalah yang telah dirumuskan pada fase awal penelitian. Teknik evaluasi sistem yang digunakan dalam penelitian ini adalah webuse method. Webuse method merupakan teknik analisis kuesioner yang melakukan evaluasi terhadap sebuah sistem yang berbasis web [8]. Metode ini berfokus pada pengembangan sistem evaluasi usability. Hasil dari webuse method adalah interpretasi nilai usability $(x)$ ke dalam bentuk predikat sangat buruk, buruk, cukup, baik, dan sangat baik.

\section{HASIL DAN PEMBAHASAN}

Berdasarkan uraian metodologi di atas, penelitian ini menghasilkan sebuah sistem informasi manajemen donasi yang direncanakan berdasarkan studi terhadap beberapa penelitian terdahulu dan data-data permasalahan yang terjadi pada studi kasus, dirancang melalui fase analisis kebutuhan berdasarkan data dan custom core system class yang dibuat secara custom, diimplementasikan dengan menerapkan model iterasi dalam pengembangannya, dan diuji menggunakan webuse method untuk mengetahui nilai usability-nya.

\subsection{Use Case}

Berdasarkan analisis terhadap permasalahan yang terjadi pada Yayasan XYZ, sistem informasi manajemen donasi dikembangkan dengan terlebih dahulu merancang diagram use 
case untuk memetakan behaviour dari sistem. Diagram use case digunakan untuk mengambarkan interaksi antara pengguna sistem (actor) dengan kasus (use case) yang disesuaikan dengan langkah-langkah (scenario) yang telah ditentukan [12]. Diagram use case dari sistem yang dikembangkan terdapat pada Gambar 3.

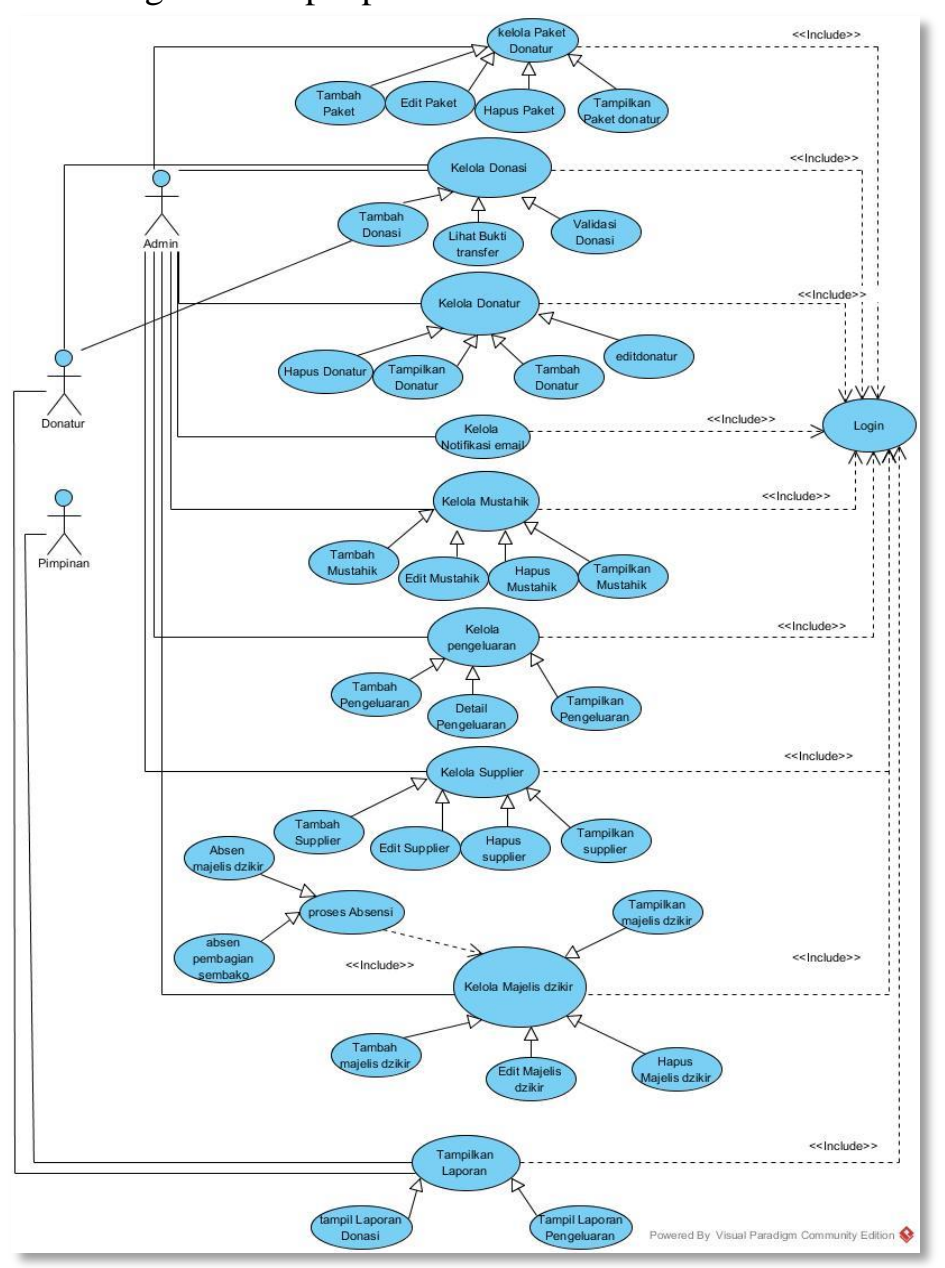

Gambar 3 Use Case Sistem Informasi Manajemen Donasi Pada Yayasan XYZ

\subsection{Custom Core System Class}

Core system class yang dibuat secara custom dalam penelitian ini dimulai dengan membangun custom model untuk kebutuhan CRUD. Custom model tersebut terdapat pada Gambar 4. 


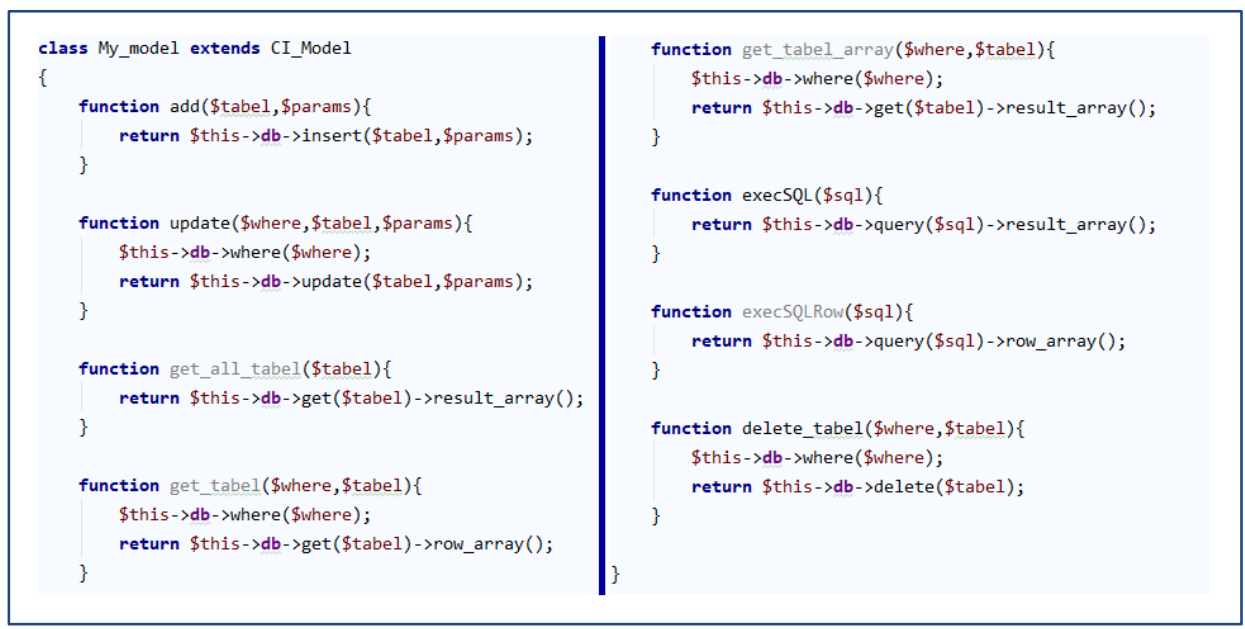

Gambar 4 Custom Model

Selanjutnya, custom core system class dengan nama MY_Controller dibangun dengan memanfaatkan custom model yang telah dibuat sebelumnya pada Gambar 4. Custom core system class tersebut terdapat pada Gambar 5.

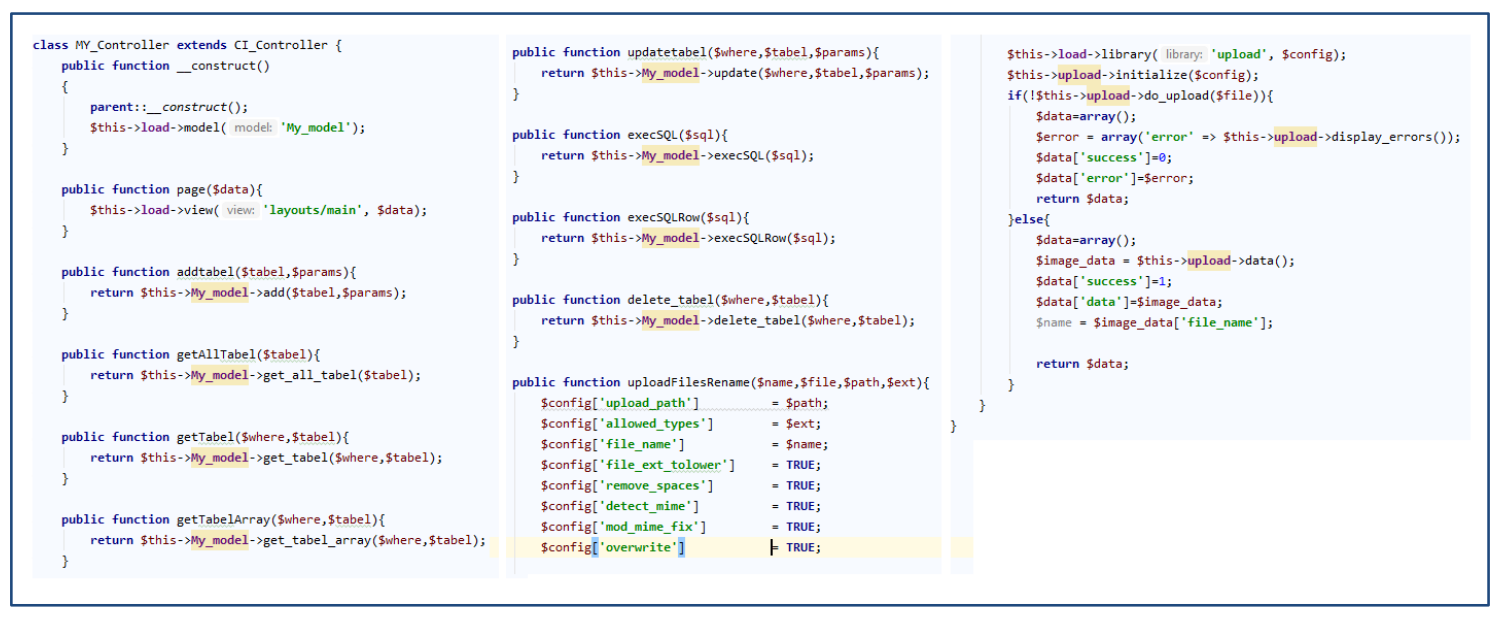

Gambar 5 Custom Core System Class

Setelah custom core system class dibangun, penggunaannya dapat dilakukan dengan memanggil method yang ada pada kelas MY_Controller, seperti 1. \$this->page(\$data) digunakan untuk memanggil halaman view, 2. \$this->addtabel(\$tabel, \$params) digunakan untuk menyimpan data ke dalam tabel melalui parameter nama tabel dan variabel-variabel yang akan disimpan (operasi CREATE), 3. \$this->getAllTabel(\$tabel) digunakan untuk mengambil semua data dari tabel tertentu tanpa kriteria where (operasi RETRIEVE), 4. \$this$>$ getTabel(\$where, \$tabel) digunakan untuk mengambil satu record data dari tabel tertentu dengan kriteria where (operasi RETRIEVE), 5. \$this->getTabelArray( \$where, \$tabel) digunakan untuk mengambil semua data dari tabel tertentu dengan kriteria where (operasi RETRIEVE), 6. \$this->update- tabel(\$where, \$tabel, \$params) digunakan untuk mengubah data dalam tabel dengan kriteria dan variabel yang menjadi parameter perubahan data (operasi UPDATE), 7. \$this->execSQL(\$sql) digunakan untuk mengambil semua data dari tabel dengan struktur query yang rumit seperti adanya operasi join terhadap beberapa tabel (operasi RETRIEVE), 8. \$this$>$ execSQLRow(\$sql) digunakan untuk mengambil satu record data dari tabel dengan struktur query yang rumit seperti adanya operasi join terhadap beberapa tabel (operasi RETRIEVE), 8. 
\$this->delete_tabel(\$where, \$tabel) digunakan untuk menghapus data dari tabel (operasi DELETE), dan 9. \$this->uploadFiles-Rename(\$name, \$file, \$path, \$ext) digunakan untuk mengunggah file ke server dengan parameter nama file, file input dari formulir, lokasi penyimpanan file, dan ekstensi dari file yang diunggah. Salah satu contoh custom core system class terdapat pada Gambar 6.

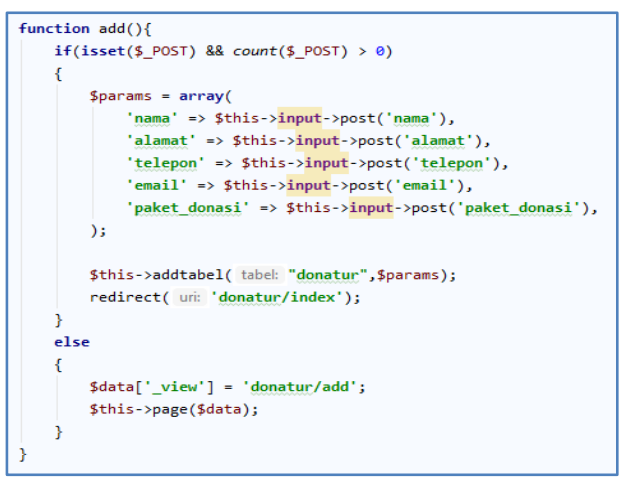

Gambar 6 Contoh Penggunaan Custom Core System Class

Gambar 6 menunjukkan penggunaan method addtabel yang digunakan untuk menyimpan data donatur ke dalam tabel donatur. Parameter donatur disimpan ke dalam bentuk array terlebih dahulu untuk kemudian disimpan ke dalam tabel donatur melalui method addtabel. Terdapat juga penggunaan method page untuk memilih view yang akan ditampilkan.

\subsection{Antar Muka Sistem}

Dengan menggunakan core system class yang telah dibangun secara custom, sistem informasi manajemen donasi yang diberi nama SIDONASI dikembangkan dengan metode pengembangan perangkat lunak iterasi. Hasil dari pengembangan sistem terdapat pada antar muka sistem sebagai berikut.

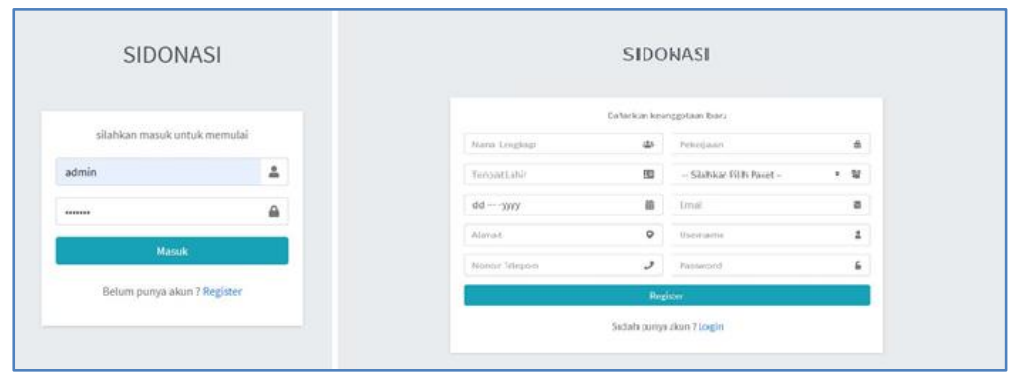

Gambar 7 Antar Muka Halaman Login Dan Registrasi 


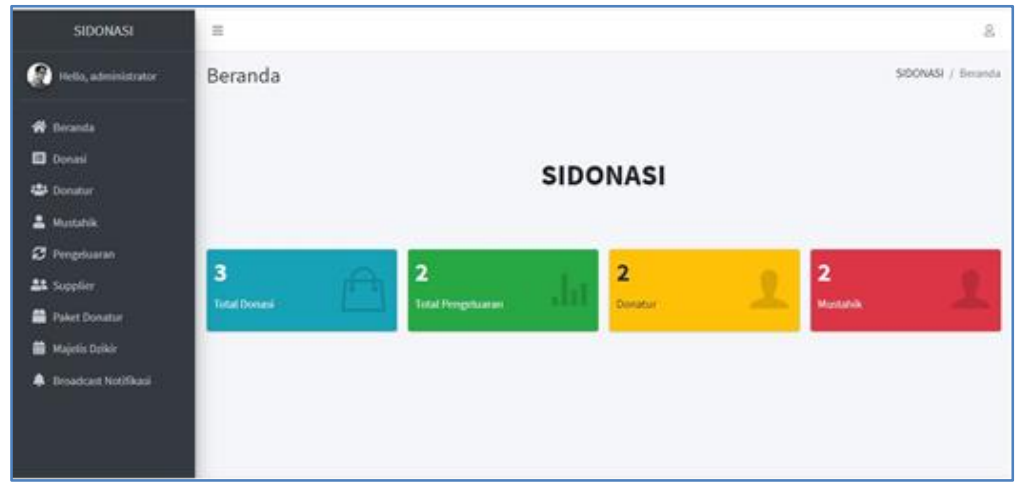

Gambar 8 Antar Muka Halaman Beranda

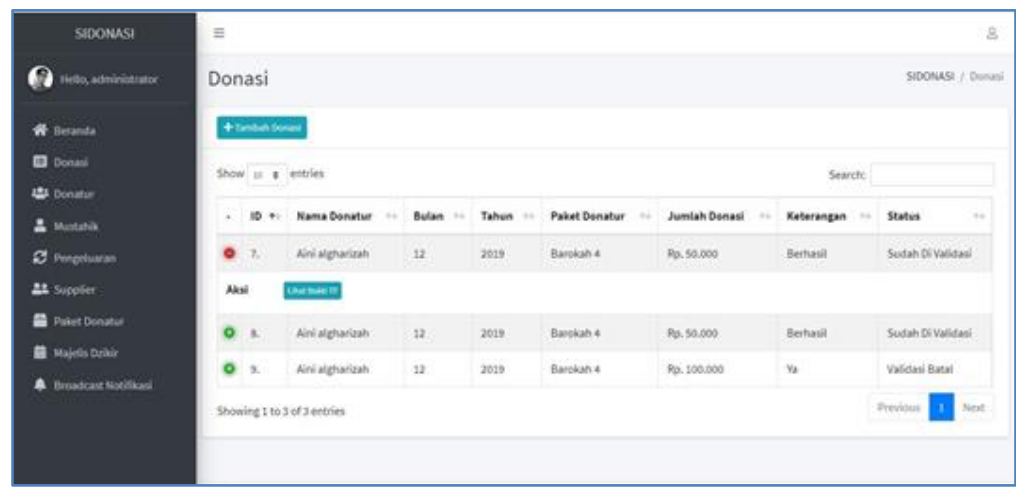

Gambar 9 Antar Muka Halaman Pengelolaan Donasi

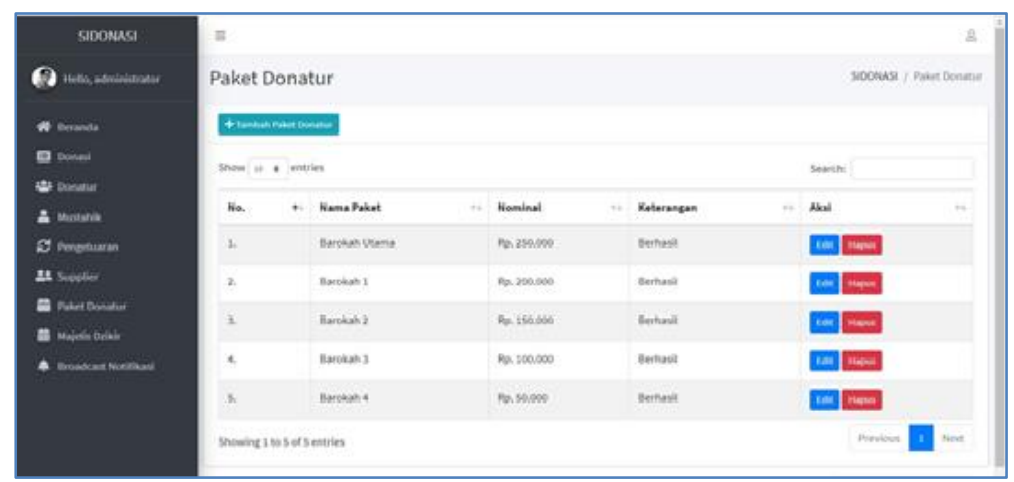

Gambar 10 Antar Muka Halaman Pengelolaan Paket Donatur

\subsection{Webuse Method}

Bagian akhir dari penelitian ini melakukan evaluasi terhadap sistem informasi manajemen donasi yang telah dikembangkan. Evaluasi ini dilakukan dengan menggunakan webuse method yang dimulai dengan kuesioner Computer Usability Satisfaction Questionnaires yang disebarkan kepada 5 orang responden pengguna sistem. Kuesioner ini berisikan 19 pertanyaan dengan alternatif jawaban 1 sampai 5 yang menunjukkan skala sangat tidak setuju (1) hingga sangat setuju (5) untuk menilai tingkat usability dari sistem [13]. Hasil kuesioner selanjutnya dipetakan per jawaban kuesioner sehingga menghasilkan skor penelitian sebagai 
berikut.

Tabel 3 Skor Penelitian Berdasarkan Webuse Method

\begin{tabular}{|c|r|r|}
\hline NILAI & JUMLAH PENILAIAN & SKOR PENELITIAN \\
\hline 1 & 0 & 0 \\
\hline 2 & 0 & 0 \\
\hline 3 & 16 & 48 \\
\hline 4 & 28 & 112 \\
\hline 5 & 51 & 255 \\
\hline \multicolumn{2}{|c|}{} & $\mathbf{4 1 5}$ \\
\hline
\end{tabular}

Berdasarkan Tabel 3, skor hasil penelitian yang didapatkan adalah 415. Sementara skor tertinggi yang diharapkan adalah 475 dari hasil perkalian jumlah responden (5), skala penilaian tertinggi (5), dan jumlah pertanyaan (19). Berdasarkan skor-skor tersebut, didapatkan nilai usability $(x)$ 0,875 dari pembagian skor hasil penelitian dan skor tertinggi yang diharapkan. Nilai $x$ yang telah diperoleh selanjutnya diinterpretasikan ke dalam bentuk predikat sesuai Tabel 4.

Tabel 4 Interpretasi Nilai Usability (X) Ke Dalam Bentuk Predikat [8]

\begin{tabular}{|c|l|}
\hline NILAI $U$ SABILITY $(\boldsymbol{X})$ & \multicolumn{1}{|c|}{ PREDIKAT } \\
\hline $0,0<x \leq 0,2$ & Sangat Buruk \\
\hline $0,2<x \leq 0,4$ & Buruk \\
\hline $0,4<x \leq 0,6$ & Cukup \\
\hline $0,6<x \leq 0,8$ & Baik \\
\hline $0,8<x \leq 1,0$ & Sangat Baik \\
\hline
\end{tabular}

Berdasarkan Tabel 4, nilai usability $(x)$ 0,875 yang dihasilkan dapat diinterpretasikan ke dalam bentuk predikat yang artinya sangat baik karena berada pada rentang $0,8<x \leq 1,0$. Hal ini menunjukkan bahwa dari sudut pandang usability, sistem informasi yang dikembangkan dengan menerapkan custom core system class pada penelitian ini memberikan hasil yang sangat baik.

\section{KESIMPULAN DAN SARAN}

Kesimpulan dari penelitian ini adalah 1. Sistem informasi manajemen donasi berbasis web yang dikembangkan dengan metode pengembangan perangkat lunak model iterasi dan dibangun menggunakan core system class yang dibuat secara custom pada framework CodeIgniter, dapat melakukan pengelolaan donasi, donatur, mustahiq, dan kegiatan penyaluran santunan pada Yayasan XYZ, 2. Custom core system class yang dikembangkan dapat diterapkan dengan melakukan pemanggilan method secara langsung di dalam class Controller sesuai dengan kebutuhan pengembangan sistem, 3. Berdasarkan evaluasi sistem yang dilakukan dengan menggunakan webuse method, sistem informasi yang dikembangkan dengan menerapkan custom core system class ini menunjukkan nilai usability 0,875 yang berarti sangat baik.

Penelitian ini dapat dilanjutkan dengan melakukan perbandingan-perbandingan terhadap kinerja dari custom core system class yang dikembangkan dalam penelitian ini dengan plain CodeIgniter yang tidak dilakukan kustomisasi di dalamnya.

\section{DAFTAR PUSTAKA}

[1] H. Bidgoli, The Handbook of Technology Management, Volume 2. Canada: John Wiley \& Sons, Inc., 2010. 
[2] K. Takahashi dan E. Liang, "Analysis and design of Web-based information systems," Comput. Networks, vol. 29, no. 8-13, hal. 1167-1180, 1997.

[3] E. UK, "Web Based Information Systems," 2018. [Daring]. Tersedia pada: https://www.ukessays.com/essays/information-systems/web-based-informationsystems.php. [Diakses: 03-Feb-2020].

[4] SimilarTech, "Market Share \& Web Usage Statistics CodeIgniter," SimilarTech Ltd. [Daring]. Tersedia pada: https://www.similartech.com/technologies/codeigniter. [Diakses: 02-Mar-2020].

[5] S. C. Wibawa et al., "Online test application development using framework CodeIgniter," IOP Conf. Ser. Mater. Sci. Eng., vol. 296, no. 1, 2018.

[6] K. Arrhioui, S. Mbarki, O. Betari, S. Roubi, dan M. Erramdani, "A Model Driven Approach for Modeling and Generating PHP CodeIgniter based Applications," Trans. Mach. Learn. Artif. Intell., vol. 5, no. 4, 2017.

[7] M. K. Fadhilah, N. Surantha, dan S. M. Isa, "Web-Based Evaluation System using Kirkpatrick Model for High School Education ( A Case Study for Vocational High School in Jakarta )," 2018 Int. Conf. Inf. Manag. Technol., no. September, hal. 166-171, 2018.

[8] T. K. Chiew dan S. S. Salim, "Webuse: Website usability evaluation tool," Malaysian J. Comput. Sci., vol. 16, no. 1, hal. 47-57, 2003.

[9] H. Al Fatta, Analisis dan Perancangan Sistem Informasi untuk Keunggulan Bersaing Perusahaan \& Organisasi Modern. Yogyakarta: Penerbit Andi, 2008.

[10] D. S. Budi, T. A. Y. Siswa, dan H. Abijono, "Analisis Pemilihan Penerapan Proyek Metodologi Pengembangan Rekayasa Perangkat Lunak," Teknika, vol. 5, no. 1, hal. 2431, 2017.

[11] C. Larman dan V. R. Basili, "Iterative and Incremental Development: A Brief History," Computer (Long. Beach. Calif)., vol. 36, no. 6, hal. 47-56, 2003.

[12] R. S. Pressman, Software Quality Engineering: A Practitioner's Approach, Seventh Ed., vol. 9781118592. New York: McGraw-Hill, 2014.

[13] T. Yamane, Elementary sampling theory. United States: Englewood Cliffs, N.J.: Prentice-Hall, 1967. 